\title{
Adoption of and Satisfaction with Islamic Online Banking: A Literature Review
}

\author{
Sri Rahayu Hijrah Hati ${ }^{1, a^{*}}$ and Tasya Aldiary Dayana ${ }^{2, b}$ \\ ${ }^{1}$ Management Department Faculty of Economics and Business Universitas Indonesia-Depok, \\ Indonesia \\ 2 Islamic Business Undergraduate Program, Management Department Faculty of Economics and \\ Business Universitas Indonesia-Depok, Indonesia \\ a sri.rahayu72@ui.ac.id, btasya.aldiary@ui.ac.id \\ ${ }^{*}$ Corresponding author
}

Keywords: Adoption, satisfaction, online banking, Islam, literature review

Abstract. Although a large body of literature on Islamic banking exists, there is a dearth of literature on Islamic online banking, especially regarding customer adoption and satisfaction. To address this gap, this paper presents a thorough review of the Islamic banking literature that has examined customer adoption of and satisfaction with Islamic online banking. Based on the literature review, the paper evaluates the antecedents of customer adoption of and satisfaction with Islamic online banking. This study concludes by offering direction for future research.

\section{Introduction}

Online banking, which refers to the method of banking in which transactions are conducted electronically via the Internet, is beneficial not only to the bank itself as it is cost-effective but also to the customers as it gives them high convenience [1], [2]. Traditional banks have become pioneers and aggressively developed online banking [3]. Thus, the utilization rate of online banking is growing steadily. Based on a survey conducted with 50,000 respondents in 2015, the utilization rate of online banking has reached $62.2 \%$ compared to $32.3 \%$ for the traditional branch [4]. Consumer satisfaction with online banking is also higher at $90.2 \%$ compared to $88.4 \%$ with the traditional branch [4].

Islamic banks, which are institutions that distribute financial resources and invest them in an attempt to accomplish predetermined and acceptable social and financial objectives [5], have also implemented online banking. However, there is a dearth of research which specifically examines customer adoption of and satisfaction with Islamic online banking. This study aims to integrate the scattered literature on Islamic online banking from the customers' perspective based on the adoption, and satisfaction dimensions.

\section{Literature review}

\subsection{Online banking adoption}

As explained earlier, the utilization of online banking had grown very high by 2015 [4]. Previous studies found that many factors influence and hinder the adoption of an online banking system. The customer's intention to adopt online banking is influenced not only by factors external to the customer such as the perceived usefulness and perceived ease of use of online banking [6],[7], but also by factors which are internal to the customer, such as self-efficacy and attitudinal factors (e.g., relative advantage, compatibility with respondents' values) [8],[9]. Factors that become barriers to the adoption of online banking are security, lack of awareness, and cost [2].

\subsection{Online banking satisfaction}

Previous studies have found that service quality leads to satisfaction with online banking [10], [11]. The dimensions of e-service quality which significantly influence customer satisfaction with online 
banking are personal need, site organization, user friendliness, efficiency of website assurance fulfillment, efficiency in system availability, privacy, contact responsiveness, and website aesthetics and guide [10], [11].

\section{Method}

To identify literature pertaining to Islamic online banking adoption and satisfaction, the researchers searched articles via Google Scholars and the ProQuest database. Multiple relevant key terms were used, such as Islamic, online banking, mobile banking, internet banking, adoption, acceptance, and satisfaction. The identified articles were restricted to peer-reviewed journals.

\section{Analysis}

\subsection{Antecedents of Islamic online banking adoption}

Like previous studies on conventional banking [6], [7], most researchers who have examined the antecedents of Islamic online banking adoption have used factors such as ease of use, perceived usefulness, and perceived benefit as the determinants of Islamic online banking adoption. Among the others, perceived usefulness and perceived benefits are the most important factors to Islamic online banking adoption [12]-[14], [16]-[18].

Table 1. Determinants of Islamic Online Banking Adoption

\begin{tabular}{cccc}
\hline Factors & Method & Country & References \\
\hline $\begin{array}{c}\text { Ease of use, website interactiv } \\
\text { customerization, assurance, } \\
\text { innovativenes }\end{array}$ & $\begin{array}{c}\text { Survey of 292 urban } \\
\text { customers }\end{array}$ & Pakistan & [12] \\
\hline $\begin{array}{c}\text { Perceived usefulness, } \\
\text { perceived ease of use, } \\
\text { perceived credibility, amount } \\
\text { of information, normative } \\
\text { pressure }\end{array}$ & Survey of 158 customers & Malaysia & {$[13]$} \\
\hline $\begin{array}{c}\text { Perceived use, perceived } \\
\text { self-expressiveness, } \\
\text { subjective norm, religious } \\
\text { affiliation and commitment }\end{array}$ & $\begin{array}{c}\text { Online survey of 135 } \\
\text { Southeast Asian students }\end{array}$ & New Zealand & [14] \\
\hline $\begin{array}{c}\text { Customer knowledge } \\
\text { Perceived benefit and social } \\
\text { influence }\end{array}$ & Survey of 600 respondents & Iran & {$[15]$} \\
\hline $\begin{array}{c}\text { Perceived self-expressiveness } \\
\text { for males; perceived }\end{array}$ & 100 Malaysian students & & {$[16]$} \\
$\begin{array}{c}\text { usefulnes and social norms } \\
\text { for females }\end{array}$ & & New Zealand & \\
\hline $\begin{array}{c}\text { Perceived ease of use, } \\
\text { perceived usefulness, attitude } \\
\text { toward using }\end{array}$ & Survey of 61 Nigerians & Malaysia \\
\hline
\end{tabular}

Only one study has examined the distinctive factor in the adoption of Islamic online banking: religious affiliation and commitment [14]. Based on the study, when the respondents were differentiated between high and low religious commitment groups, only perceived self-expressiveness and subjective norm are significant for the high religious commitment group while only perceived usefulness is significant for the low religious commitment group. 


\subsection{Antecedents of Islamic online banking satisfaction}

Like the antecedents of Islamic online banking adoption, most of the studies that have investigated the antecedents of Islamic online banking satisfaction have used conventional factors, especially for the service quality dimensions. However, it is interesting to note that one study found attitude toward halal banking to be an important factor for customer satisfaction with using Islamic online banking [12]. The results show the importance of Islamic values in the formation of attitude in attempts to increase customer satisfaction.

Table 2. Determinants of Islamic Banking Satisfaction

\begin{tabular}{cccc}
\hline Factors & Method & Country & References \\
\hline $\begin{array}{c}\text { Service quality, attitude } \\
\text { toward halal banking }\end{array}$ & $\begin{array}{c}\text { Survey of 292 urban } \\
\text { customers }\end{array}$ & Pakistan & {$[12]$} \\
\hline $\begin{array}{c}\text { Accuracy, reliability, } \\
\text { image, impression of the } \\
\text { bank and management, } \\
\text { website design }\end{array}$ & - & Iran & {$[19]$} \\
\hline $\begin{array}{c}\text { Accessibility, } \\
\text { convenience, accuracy, } \\
\text { security, usefulness, web } \\
\text { design, bank image }\end{array}$ & $\begin{array}{c}\text { Survey of electronic } \\
\text { banking consumers }\end{array}$ & Iran & {$[20]$} \\
\hline
\end{tabular}

\section{Summary}

The study reveals the need for research that specifically examines the determinants of adoption of and satisfaction with Islamic online banking. The results also show that most studies have used conventional variables to examine customers in Islamic online banking adoption; only a few studies have included specific variables related to religion and Islamic values (e.g., attitude toward halal banking, religious commitment). Therefore, further investigation into the specific values related to Islam is expected to provide a better understanding of the determinants of consumers' adoption of and satisfaction with Islamic online banking.

\section{Acknowledgment}

This research was financially supported by a PITTA Grant to Directorate Research and Community Services Universitas Indonesia.

\section{References}

[1] H. Karjaluoto, T. Koivum??ki, and J. Salo, "Individual differences in private banking: Empirical evidence from Finland," in Proceedings of the 36th Annual Hawaii International Conference on System Sciences, HICSS 2003, 2003.

[2] M. Sathye, "Adoption of Internet banking by Australian consumers: an empirical investigation," Int. J. Bank Mark., vol. 17, no. 7, pp. 324-334, 1999.

[3] T. Pikkarainen, K. Pikkarainen, H. Karjaluoto, and S. Pahnila, "Consumer acceptance of online banking: an extension of the technology acceptance model," Internet Res., vol. 14, no. 3, pp. 224-235, 2004.

[4] N. Morris, "Internet banking growth and satisfaction outstrips other channels," 2015. .

[5] Al Baraka, "Principles of Islamic Banking." . 
[6] C. Yiu, K. Grant, and D. Edgar, "Factors affecting the adoption of Internet Banking in Hong Kong-implications for the banking sector," Int. J. Inf. Manage., vol. 27, no. 5, pp. 336-351, 2007.

[7] W. Nasri and L. Charfeddine, "Factors affecting the adoption of Internet banking in Tunisia: An integration theory of acceptance model and theory of planned behavior," J. High Technol. Manag. Res., vol. 23, no. 1, pp. 1-14, 2012.

[8] K. S. Tan, S. C. Chong, P. L. Loh, and B. Lin, "An evaluation of e-banking and m-banking adoption factors and preference in Malaysia: a case study," Int. J. Mob. Commun., vol. 8, no. 5, p. 507, 2010.

[9] S. Chan and M. Lu, "Understanding internet banking adoption and use behavior: a Hong Kong perspective," J. Glob. Inf. Manag., vol. 12, no. 3, pp. 21-43, 2004.

[10]M. S. M. Ariff, L. O. Yun, N. Zakuan, and K. Ismail, “The Impacts of Service Quality and Customer Satisfaction on Customer Loyalty in Internet Banking," Procedia - Soc. Behav. Sci., vol. 81, pp. 469-473, 2013.

[11] M. Amin, "Internet banking service quality and its implication on e-customer satisfaction and e-customer loyalty," Int. J. Bank Mark., vol. 34, no. 3, pp. 280-306, 2016.

[12] M. M. Butt and M. Aftab, "Incorporating attitude towards Halal banking in an integrated service quality, satisfaction, trust and loyalty model in online Islamic banking context," Int. J. Bank Mark., vol. 31, no. 1, pp. 6-23, 2013.

[13]H. Amin, M. R. A. Hamida, S. Ladaa, and A. Zuraidah, "The Adoption of Mobile Banking in Malaysia: The Case of Bank Islam Malaysia Berhad (BIMB)," Int. J. Bus. Soc., vol. 17, no. 3, pp. 43-53, 2016.

[14] S. Sun, T. Goh, K.-S. Fam, and X. Yang, "The influence of religion on Islamic mobile phone banking services adoption," J. Islam. Mark., vol. 3, no. 1, pp. 81-98, 2012.

[15] M. Salehi and M. Alipour, "E-Banking in Emerging Economy: Empirical Evidence of Iran," Int. J. Econ. Financ., vol. 2, no. 1, pp. 201-209, 2010.

[16] R. Safeena, A. Kammani, and H. Date, “Assessment of Internet Banking Adoption: An Empirical Analysis," Arab. J. Sci. Eng., vol. 39, no. 2, pp. 837-849, 2014.

[17]T. T. Goh and S. Sun, "Exploring gender differences in Islamic mobile banking acceptance," Electron. Commer. Res., vol. 14, no. 4, pp. 435-458, 2014.

[18]B. U. Dalhatu, A. B. Abdullah, M. Y. Ibrahim, and A. Abideen, "Nigerian Retail Customers' Adoption of Online Banking in an Islamic Bank," Glob. Bus. Manag. Res. An Int. Journa, vol. 6, no. 3, pp. 237-245, 2014.

[19] T. Sadeghi and K. H. Hanzaee, "Customer satisfaction factors (CSFs) with online banking services in an Islamic country: I.R. Iran,” J. Islam. Mark., vol. ', no. 3, pp. 249-267, 2010.

[20]T. Sadeghi and S. Farokhian, "The Role of Behavioral Adoption Theories in Online Banking Services," Middle-East J. Sci. Res., vol. 7, no. 3, pp. 374-380, 2011. 